\title{
Maintaining e3-learning while transitioning to online instruction: The case of the Open University of Indonesia
}

Article in Distance Education · August 2008

DOI: $10.1080 / 01587910802154962$

\section{CITATIONS}

12

3 authors:

Thomas F. Luschei

Claremont Graduate University

37 PUBLICATIONS 278 CITATIONS

SEE PROFILE
READS

72

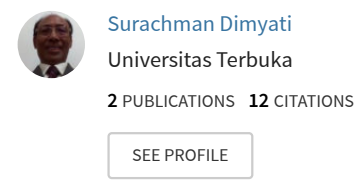

Dewi Padmo

Universitas Terbuka

7 PUBLICATIONS 14 CITATIONS

SEE PROFILE

Some of the authors of this publication are also working on these related projects:

Project Developing perspective: What can the South teach the North about education? View project 


\title{
Maintaining $\mathrm{e}^{3}$-learning while transitioning to online instruction: the case of the Open University of Indonesia
}

\author{
Thomas F. Luschei ${ }^{\mathrm{a} *}$, Surachman Dimyati ${ }^{\mathrm{b}}$ and Dewi Padmo ${ }^{\mathrm{b}}$ \\ ${ }^{a}$ Florida State University, Tallahassee, FL, USA, ${ }^{b}$ Universitas Terbuka, Jakarta, Indonesia
}

(Received 29 February 2008; final version received 6 May 2008)

\begin{abstract}
The Open University of Indonesia (Universitas Terbuka, UT) has over 450,000 students distributed across a vast, diverse archipelago. UT will play a central role in meeting the requirement that over 1 million primary teachers earn four-year postsecondary degrees by 2015 . While the Open University has considerable capacity in print-based and CDROM-based instruction, the university must begin to provide its students with greater online learning opportunities. In this article we describe the challenges faced by the Open University in augmenting online instruction. Lessons learned from the university's history of print-based distance education, combined with growing experience with online instruction at both the undergraduate and graduate levels, provide a way forward as the Open University increases online instruction of in-service teachers while maintaining and enhancing efficient, effective, and engaging learning.
\end{abstract}

Keywords: distance education; Indonesia; online learning; teacher education

\section{Introduction}

In 2005, the Indonesian government approved legislation requiring that all primary teachers in the country hold four-year postsecondary degrees by 2015. Given Indonesian teachers' current educational levels, this was an ambitious goal: in 2004, only $8 \%$ of the country's primary teachers held the required degree. Assuming that current teachers remain in the primary teacher workforce until 2015, over 1.1 million practicing teachers must earn fouryear degrees by 2015 in order to comply with government requirements (Jalal, 2006). Given teachers' demanding schedules and limited opportunities to engage in face-to-face instruction at local universities, distance education (DE) must be a central strategy in the Indonesian government's efforts to improve the knowledge and skills of its teachers. In short, Indonesia's push to upgrade its primary teachers places an enormous challenge on the country's largest university, the Open University of Indonesia, or Universitas Terbuka (UT).

Although UT has established an effective and efficient system to train teachers through print-based DE, its experiences in online instruction are limited. Yet increasing demand for teacher training is likely to require greater use of Web-based approaches. As UT embarks on this ambitious project, it can draw on many experiences and lessons learned from its history as Indonesia's largest teacher training institution. These lessons are based on earlier experiences with Web-based administration and instruction, over two decades of distance teacher education, and research to improve instructional effectiveness. These experiences will not only inform UT's transition to online instruction, but they can also serve as a model

\footnotetext{
*Corresponding author. Email: tluschei@1si.fsu.edu
} 
for universities in developing countries facing the challenge of training large populations of working professionals. The fundamental thrust of this article is that methods and processes established for efficient, effective, and engaging print-based instruction can inform online learning as well. Although some argue that online learning requires a new approach to instructional design and development, UT's experience suggests that this is not necessarily the case, at least not in all circumstances.

\section{DE in Asia}

Baggaley (2007) has argued that Asia has reached a crossroads whereby it must choose to either take a 'developed country' route or 'distinctive Asian trails' (p. 127) to deliver DE. Baggaley illustrated this dichotomy with the examples of Bhutan, which has embraced a Western model of information and communication technology (ICT) use in its distance teacher education program, and the Philippines and Mongolia, countries that have made use of cell phones for both formal and non-formal DE.

What sets Asian DE apart? In a recent interview in this journal, Dr Tian Belawati, UT's Vice Rector for Academic Affairs, observed that distance educators in most Asian countries face similar issues of large populations, high poverty, and poor ICT infrastructure, which combine to limit access to higher education (Baggaley, Belawati, Malik, \& Ng Lee Hoon, 2007). DE in these countries has developed in order to provide educational access to large populations straining the capacity of traditional universities. In contrast with this access paradigm, developed countries have operated under a quality paradigm. According to Belawati, 'the expectation of higher-quality DE using more advanced technologies is inevitable, and Asian DE institutions have been struggling to balance these two paradigms' (Baggaley et al., 2007 , p. 251). Moreover, as Jung $(2005,2007)$ has pointed out, a quality culture has begun to take root in many Asian open and distance learning (ODL) institutions, especially the continent's mega-universities with over 100,000 students.

ICT infrastructure in Asia has also improved dramatically in recent years: growth rates in ICT indicators such as fixed land lines, mobile subscribers, and Internet users have been much higher in Asia than many other regions (Jung, 2007). As this infrastructure continues to develop, both ODL and conventional institutions in Asia will be able to offer completely online courses and programs. Increasing ICT use in education has also resulted in greater educational opportunities for traditionally underserved populations in developing countries such as Bhutan and Cambodia (Jung, 2007). In a pilot study at UT, Belawati (2005) found that students' participation in online tutorials increased both achievement and course completion rates, suggesting that ICT-based instruction can address some of the traditional challenges of print-based DE (Jung, 2007).

DE institutions in Asia often must also meet greater expectations in terms of their roles relative to traditional higher education institutions. Malik observed that in contrast to developed nations where DE is oriented toward lifelong learning and the facilitation of midcareer changes by those already in the workforce, DE in Asia often supplements the capacity of conventional institutions, many of which face significant quality constraints. In this context, "the rigorous content development and review methods generally employed by DE institutions result in study materials with the potential to deliver quality education to large student cohorts' (Baggaley et al., 2007, p. 252).

There are of course major differences in modes of DE delivery between developed and developing countries. While developed countries primarily use ICT-based approaches, ODL institutions in developing countries, including Indonesia, rely on print-based materials and delivery, occasionally supplemented with CD-ROM-based multimedia. ICT-based 
approaches in Indonesia have only reached an experimental stage. The key factors impeding the greater use of ICTs in DE are a lack of ICT infrastructure and low levels of comfort and familiarity of many instructors and students with the Internet. Belawati (2005) has argued that DE institutions in countries like Indonesia must take on the role of socializing and educating students, educators, and society to use ICT facilities for DE.

\section{UT: background, strengths, and challenges}

UT was founded by presidential decree in 1984 to provide higher education - particularly teacher training - to a growing population of secondary school graduates whom conventional universities could not accommodate (Daniel, 1996). Since its establishment, UT has played an increasingly central role in training Indonesia's teachers. In 2007 , UT trained $11 \%$ of the country's 2.7 million classroom teachers; by 2007 , nearly $20.2 \%$ of the primary teacher workforce (about 250,000 teachers) had received two-year postsecondary degrees from UT. Total enrolment in 2007 reached over 450,000 students in more than 1000 courses in 34 study programs offered by four undergraduate faculties: Economics and Developmental Studies, Social and Political Sciences, Mathematics and Natural Sciences, and Teacher Training and Educational Services. UT also has a graduate studies program that offers master's degrees in management, public administration, and fisheries management.

As an open university, UT accepts all students who apply and has no time limitation or dropout system. To ensure that students in remote areas have access to materials and support, UT has 37 regional centers that are responsible for carrying out operational activities in local areas. Activities conducted by the regional centers include handling student registration, organizing face-to-face tutorials, providing administrative counseling, organizing examinations, and working with local universities to identify practicum instructors, exam supervisors, and face-to-face tutors (Belawati, 2005).

Most students attending UT work full time and may live in rural areas, where qualified tutors are often difficult to find. As a result, DE that makes use of asynchronous meetings and allows flexibility in student schedules is a must. Students' difficult schedules, along with limited support from tutors and instructors, result in high rates of course failure and inability to complete programs. Belawati (1998) found that the average degree completion rate for students who first registered at UT between 1984 and 1990 was only 4.8\%. Nevertheless, UT has a great cost advantage over other Indonesian universities. A 1996 study estimated that UT's cost per graduate was approximately one-third that of three conventional Indonesian universities and the cost to the government for each UT graduate was only $29 \%$ the cost of graduates from other Indonesian universities. Consequently, despite lower graduation and completion rates, UT is actually more efficient than many conventional Indonesian universities. To the extent that greater incorporation of instructional technology can raise graduation rates, efficiency at UT is likely to increase (Daniel, 1996).

\section{Web-based approaches to administration and instruction}

While UT's mode of instruction is largely print based, the university has progressively increased ICT use in both administration and instruction. Since 1997, UT has provided Web-based services for general academic and administrative information. Furthermore, Web-based services have expanded to the online publication of research reports, announcement of examination results, distribution of supplementary course materials and take-home examinations, and some use of online tutorials to support instruction. In 2001, UT launched UT-Online to provide counseling, video lectures, and online lectures for a pilot project of 
seven newly converted Web courses. By 2006, UT-Online was available at Internet kiosks in six major Indonesian cities (Sardjiyo \& Pannen, 2006).

A 1999 study of UT students' access to the Internet found that $33 \%$ of students surveyed were within a 30-minute trip to an Internet kiosk and approximately $40 \%$ of students could access the Internet from their offices (Hardhono \& Belawati, 1999, as cited in Belawati, 2005 , p. 17). However, UT students generally have low purchasing power and find it difficult to pay Internet fees. Availability of these kiosks is also much lower in rural areas, where many UT students live. Yet past collaboration between UT and Internet access providers has resulted in discounted rates for UT students and establishment of kiosks in areas where many UT students are concentrated (Belawati, 2005).

Another challenge for UT's use of Web-based courses is the lack of human resources in terms of technicians, operators, supervisors, designers, and instructors. A study of the development of seven Web-based courses at UT (mentioned above) found that many faculty members had misconceptions regarding the nature and function of such courses. As Sardjiyo and Pannen (2006) reported, the majority of faculty members 'stated clearly that they did not have any idea at all' about Web-based courses (p. 38). Despite these problems, faculty members generally had positive impressions of the Web-based courses and felt that UT should develop more of them. But they also expressed the importance of more careful planning on the part of UT in selecting courses to be developed, making the system more accessible and reliable, and training faculty members, technicians, and instructional designers on e-learning and Web-based courses (Sardjiyo \& Pannen, 2006).

\section{Undergraduate programs at $U T$}

UT is primarily an undergraduate institution and each of its four faculties offers degrees that require from one year to four years of postsecondary study. Given UT's important teacher training function, its largest faculty is Teacher Training and Educational Services, which enrolls approximately 300,000 active students, compared to 86,000 in the other faculties combined. Printed modules are the major medium of instruction in UT's undergraduate programs. These are often supplemented with multimedia learning materials such as audio and videocassettes, CDs, CD-ROMs, radio and TV broadcasts, computer-assisted instruction, or Internet-based learning materials. Additionally, UT plans to place all undergraduate learning materials in its digital library by 2008. UT's learning materials are developed by well-known content area experts from universities across Indonesia and are often used by other Indonesian universities.

Instruction in UT's undergraduate courses occurs primarily through two-hour face-toface tutorials that meet an average of eight times a semester. Some courses also make limited use of distance tutorials through telephone, correspondence, radio, television, and the Internet. Face-to-face tutorials are facilitated by tutors, instructors, and supervisors who are instructors at UT or other Indonesian universities, while UT's academic staff members facilitate the university's online tutorials. Although the use of online tutorials at UT is still limited, student participation in these tutorials increased from 7.4 to $10.3 \%$ between 2006 and 2007 .

Assessment in UT's undergraduate programs occurs through the use of tutorial assignments, practical works, practicum assignments, and an examination at the end of each semester. These examinations comprise supervised written tests that all students across the country take simultaneously. Students pursuing their baccalaureate or four-year degrees also must complete a final assignment before receiving their degrees. Beginning in 2007, students are also encouraged to participate in online tutorials as they prepare their final assignments. Participation in these tutorials can contribute up to $50 \%$ of a student's final 
grade. Gradually, the use of online tutorials to prepare for final assignments will become obligatory for all students.

UT will undoubtedly play a major role in meeting government requirements to upgrade primary teachers to four-year degrees. The university has already seen an indication of the effects that this legislation will have on demand for its courses: between 2002 (when the four-year degree program was first offered) and 2007, enrolment in the program increased from 605 to 110,000 students. Increasing enrolments may place too great of a burden on UT's primarily print-based method of course delivery. In particular, finding tutors, arranging face-to-face tutorials, scoring examinations, and supervising final projects will require greater use of ICT-based methods, such as online discussions and tutorials. Of course, use of these methods faces many of the challenges discussed above, including limited infrastructure, particularly in rural areas, and limited experience and ease of both tutors and classroom teachers in the use of these technologies. For example, undergraduate students who were surveyed during a pilot study of the use of online tutorials in 160 courses reported time constraints, lack of computer facilities, unavailability of Internet kiosks, and high costs. Students also cited problems with the responsiveness of tutors, the appearance of UT's website, and lack of information on how to navigate applications. Yet although $29 \%$ of the 755 surveyed students reported having some technical difficulties with the online tutorials, $21 \%$ found the UT-Online service to be satisfactory. Additionally, $17 \%$ felt that UT should expand its use of online tutorials and courses. Students participating in the online tutorials also had on average higher completion rates and grade point averages than those students who did not (Belawati, 2005). An earlier study at UT also found that the use of the Internet to counsel students resulted in greater course completion (Belawati, 1998).

\section{Graduate programs at $U T$}

The Graduate Studies Program at UT was established in 2004. The program has three master's level programs: public administration, management, and fishery management. Graduate programs were initially available only for students living near regional offices with welldeveloped Internet support, which limited availability to regional offices in Jakarta, Medan, Banda Aceh, Ternate, and Denpasar. However, enrolment is expanding to new regions where students can reach regional offices through personal car, chartered buses, boats, or air.

The teaching process for all graduate courses includes eight online tutorials and four face-to-face sessions per semester. Academic staff at UT's head office provide online tutoring, while face-to-face tutors come from universities near UT's regional offices. Online communication and discussion forums are central to instruction. Course materials include a combination of printed learning materials enhanced by Internet-based learning, including online tutorials and Web-based supplements. In 2007, representatives of the Graduate Studies Program also submitted a proposal to the Indonesian Ministry of National Education to establish a videoconferencing seminar enabling communication between students, face-toface tutors, and online tutors via Indonesia's university intranet system. The purpose of the proposed seminar is to introduce students to the use of advanced technology and to enable exchange of ideas among UT academic staff, guest lecturers, and local government officials (Dimyati et al., 2007).

Assessment in the Graduate Studies Program occurs through automatic scoring of Webbased participation, three online tasks that are scored by face-to-face tutors in regional offices, and written examinations that are quite different from multiple-choice examinations used by the undergraduate programs. In order to graduate with their master's degrees, students must write a thesis and pass a final oral exam. 
While UT's Graduate Studies Program is relatively new and must be studied further, early results indicate that the program has been successful in recruiting and preparing students. Between 2004 and 2007, enrolment increased from 26 students in 3 regions to more than 560 students in 13 regions. Additionally, most graduates surpass the minimum grade point average of 3.0, and 14 of 15 management students in the Medan office graduated in only four to five semesters. These successes are due to several factors. First, because all courses require participation in online instruction, instructors have significant experience in the use of Internet and online tutorials. Second, graduate students tend to be wealthier than undergraduate students and are more likely to live in urban areas with greater access to the Internet. Because the cost of graduate tuition is approximately 16 times that of undergraduate tuition, UT's graduate programs are often limited to wealthy students and those who receive scholarships from local governments. However, local governments in many regions have appeared increasingly more willing to support the training of their young people.

While UT's undergraduate students cannot replicate the economic status of the graduate students, the undergraduate programs can take several lessons from graduate studies. Gradual implementation of requirements to participate in online tutorials could encourage greater student participation and promote familiarity of tutors with such approaches. The experiences of the postgraduate students also demonstrate that it is possible for working professionals to succeed in ICT-based DE despite the heavy demands of full-time work. In general, UT graduate students can access free Internet from their offices and often read and discuss their work with other students after office hours and on weekends. These students also commonly pay tutors for extra face-to-face support. While working teachers may not have the luxury of free Internet access or paid tutors, they can certainly work with other colleagues to discuss ideas and course assignments. With over 110,000 working teachers participating in UT's courses, it is likely that most teachers studying at UT have colleagues nearby who are also UT students.

\section{Print-based instruction informing design and delivery of online courses}

In developing online courses and tutorials, UT has built on successful methods and processes established in their print-based programs. Just as the Indonesian context requires that the university employ a variety of approaches for print-based courses (delivery of instructional materials via regular mail, meeting with tutors at regional centers, occasional access to CD-ROM-based multimedia, radio and television broadcasts), a similar blend of methods has proved to be effective in UT's online programs. Courses in UT's Graduate Studies Program combine online tutorials, face-to-face instruction, online discussion, printed learning materials with Internet-based learning, and videoconference seminars. In fact, UT's Web-based courses might well be considered hybrid courses, because many of the features of the print-based programs are retained in the form of an online counterpart. For example, online courses feature online meetings with tutors as a parallel to face-to-face tutorials used in print-based courses. Moreover, most online courses incorporate some aspect of face-to-face learning.

Greater use of online courses and tutorials may also help to improve on certain aspects of UT's print-based courses. In a 1998 study of persistence among UT students, Belawati (1998) observed that in some respects, UT failed to adopt some of the more crucial elements of Western DE, particularly support systems such as tutorials, counseling, and consistent feedback. Belawati argued that while Indonesian students - due to cultural and educational factors - may need more of this type of support than, for example, students of Britain's Open University, they generally receive much less of it. In contrast to strong support systems at 
Britain's Open University, 'UT uses mainly printed materials and limited face-to-face tutorials' (p. 106). Furthermore, in UT's adaptation of foreign DE models, 'the support systems required by this method, such as tutorials, counseling, feedback, and payment flexibility were disregarded' (p. 107). Lack of support may be largely responsible for UT's low levels of student persistence in courses and programs. To the extent that online course provision can overcome geographic and financial barriers to provide more consistent support to students, Web-based approaches may help to increase student persistence.

A pilot project by UT to develop and test the use of online tutorials demonstrated both the potential to improve student support through these approaches and the problems that such attempts face. The development of these pilot tutorials consisted of a preparatory phase and an intervention phase (Belawati, 2005). During the preparation stage, a communication network was established through agreements with Indonesian Internet service providers. UT also used printed materials, seminars, and short training courses to introduce its students to the use and advantages of the Internet. During the intervention phase, UT's online tutors used an open-source-based learning management system to provide supplementary materials, have asynchronous interactions with students, and facilitate student discussions. Tutors encouraged discussions through the use of materials that included further elaboration of concepts, enrichment, summaries of course materials, and questions. Online tutorials remained open to allow questions, comments, and responses throughout the semester. UT also requested that tutors promptly respond to all questions. As an added incentive for students to participate in the voluntary tutorials, participation contributed to up to $10 \%$ of their final grade (Belawati, 2005).

Although surveyed students generally responded positively to the online tutorials, they reported problems with tutor responsiveness. According to Belawati (2005), this response was 'disappointing for UT because ... all tutors had participated in a training on e-tutoring ... and had been provided with technical as well as academic guidelines for e-tutoring' (p. 23). This example underscores a difficult paradox in UT's growing efforts to provide greater Web-based instruction: while online courses and tutorials offer greater possibilities to provide immediate support to students, limited experience with Web-based instruction may impede tutors and instructors from providing this support. Nonetheless, students participating in the pilot online tutorials did enjoy higher course completion rates and grade point averages than those who did not participate (Belawati, 2005).

\section{The role of research and evaluation in improving instruction}

UT has undertaken both international and internal research to identify the most effective instructional approaches and uses of ICTs. Internationally, UT is collaborating on three research projects sponsored by Canada's International Development Research Centre (IDRC). The IDRC's Pan Asia Networking division is funding distance learning technology and research projects that encourage collaboration of educators and researchers from Bhutan, Cambodia, China, Hong Kong, India, Indonesia, Laos, Mongolia, Pakistan, the Philippines, Sri Lanka, Thailand, and Vietnam. As Indonesia's representative on this PANdora project, UT pledged to collaborate on projects involving evaluation and customization of open-source software in DE, developing a repository of reusable learning objects for DE, and e-assessment methods and models for student evaluation. Belawati observed that the effort to balance access with quality 'calls for a comprehensive and longitudinal R\&D program of the type PANdora is providing, in the hope of identifying the most appropriate advanced technologies and the most suitable applications of them for delivering DE in the Asian context' (Baggaley et al., 2007, p. 251). 
In addition to international research efforts, UT also undertakes internal research regarding effectiveness of its course materials and instruction. UT's Institute for Research and Community Services houses two related research centers: the Center for Institutional Research and System Development (Puslitgasis), which issues proposals for faculty research on instructional effectiveness, and the Inter-University Center for Improving and Developing Instructional Activities (IUC-IDIA). The role of the IUC-IDIA is to improve the capabilities of academic staff in instructional design and other skills needed to become lecturers at UT and other universities. Puslitgasis coordinates and supports faculty research in instructional effectiveness. However, faculty members generally undertake research in their respective fields, such as economics or education, rather than the instructional effectiveness of their courses. Moreover, UT has no instructional systems or distance learning program to house faculty members actively conducting research in this area.

\section{UT: lessons learned and future directions}

Despite many limitations, greater use of the Internet by Indonesian teachers looks promising in upcoming years. Networks linking schools around the country and local, regional, and national departments of education have developed significantly. Teachers and students in large cities are now accustomed to using the Internet for both academic and administrative communication. The Internet is also widely used in most universities in larger Indonesian cities and almost all universities on the island of Java. Teachers graduating from these universities increasingly have good experience and knowledge of the Internet.

Increasing access and familiarity with the Internet will go far in facilitating UT's use of online instruction. Several other lessons learned can also help to guide UT. First, UT must draw on its experience using the Internet for administrative and academic functions, as well as conducting pilot programs in online undergraduate instruction. One lesson from this experience is that students often have trouble paying for the costs of Internet service. Partnerships between UT and Indonesian Internet service providers to give discounts to UT students, for which there is already a precedent, will be necessary to ensure equal access of students regardless of their ability to pay. These experiences also indicate that UT staff and students alike must improve their knowledge of and ease with the Internet. While this is a challenge, instructors, tutors, and students have generally responded positively to the online experiences that they have had, and there is some evidence that online approaches can increase course and program completion. Additionally, simple adjustments, such as improving the design of the UT-Online website, may prompt greater use by students. Furthermore, tutors must respond promptly and effectively to students' questions and concerns, especially during students' first experiences with online courses.

A second lessoned learned for UT - as demonstrated by the university's Graduate Studies Program - is that online approaches can successfully provide high-quality instruction to working professionals. While not all of the features of this program can be transferred to teacher education, it is important to recognize and, to the extent possible, replicate this experience for classroom teachers. In particular, online instructors and tutors must receive extensive training in how to conduct online discussions and other activities. Also, a large part of the reason that undergraduate students have low participation rates in existing online tutorials is that participation in these tutorials is voluntary. UT can encourage greater participation by either offering extra credit for online participation or gradually making participation in online tutorials mandatory for course or program completion. What's more, UT and its regional centers can help to facilitate collaboration of classroom teachers in discussing assignments, accessing the Internet, and completing online tutorials. 
Third, in terms of the nature and content of UT's online courses and tutorials, lessons learned from print-based courses have provided strong models for employing a blend of approaches and materials. Web-based approaches have the potential to offer much more immediate and individualized support to students, a key to increasing course and program persistence rates; instructors and tutors must learn to make use of these opportunities through greater familiarity and use of online approaches.

Fourth, research into instructional effectiveness and student satisfaction with new approaches is likely to support UT's efforts to undertake new approaches. While UT engages in internal research on the effectiveness of its instructional programs, the establishment of an instructional systems program, perhaps at the graduate level, would bring greater expertise and work to the university and allow stronger evaluation of growing Internet-based programs. Additionally, UT's collaboration with other Asian universities through the PANdora project is likely to result in sharing of successful approaches with other universities.

A final lesson learned for UT is that collaboration with universities across Asia will help the university to address more general concerns facing developing countries as they seek to reach more students with online instruction. To begin with, UT and Indonesia must engage in a socialization and public relations campaign to convince Indonesians of the utility of ICT-based instruction. As Belawati and Zuhairi (2007) observed, ODL institutions in developing countries must 'socialize and educate students, educators and the society in using ICT facilities for the ODL enterprise’ (p. 4). UT also must consider using a blend of developed country and uniquely Asian approaches (Baggaley, 2007). While UT has used what could be considered as developed country approaches, the university must also be open to innovative possibilities that better match the Indonesian context. For example, recent experiences in the Philippines and Mongolia have prompted UT's Vice Rector, Dr Tian Belawati, to observe that the cell phone is the 'most promising technology for Asian DE generally' (Baggaley et al., 2007, p. 250).

\section{Conclusion}

Belawati (2005) has observed that in terms of ensuring quality in learning processes, 'the challenge for ODL institutions ... is not only to ensure learner support that is both accessible and relevant, but also to encourage students to participate in and use support systems that ensure quality learning' (p. 4). Encouragement of students lies at the heart of the task ahead as UT transitions to greater use of online instruction. The fact that these students are also classroom teachers makes this one of the most important educational tasks facing Indonesia. Consequently, this work must be shared by many educational stakeholders, including the Indonesian government, other universities, and schools and teachers themselves. Socialization toward online learning, as well as continuing development of ICT infrastructure, must occur at all levels of Indonesia's education system. But due to its central role and experience with DE of teachers, UT must be a leader in this effort.

UT's experiences with DE and ICT-based instruction, as well as its strong commitment to quality and continued research, offer many lessons for maintaining efficient, effective, and engaging learning while transitioning to online instruction. Perhaps most importantly, UT has adopted many of the same methods and processes that proved effective in printbased settings as models for online programs. While designing learning to be effective is a challenge for many different settings, the specific situation in Indonesia required a blend of methods for the traditional print-based courses. A similar blend of methods is proving to be effective with regard to UT's online graduate programs. 
While this article offers some suggestions and lessons learned for UT to follow during the transition to online learning, the authors believe that discussion of UT's practices and philosophies should provide lessons for other developing countries with diverse and remote populations striving for higher education opportunities.

\section{Notes on contributors}

Thomas F. Luschei is an assistant professor of education policy at the Learning Systems Institute and College of Education, Florida State University. His interests include international comparative education, the economics of education, teacher labor markets, and teacher education.

Surachman Dimyati is the assistant director of Administration and Financial Affairs of the Graduate Studies Program, Universitas Terbuka, Jakarta, Indonesia. His interests include science education in primary schools, the use of virtual laboratories to teach science, and the role of ICTs in improving basic education.

Dewi Padmo is head of the Institute of Learning Materials Development, Examination, and Information Systems, Universitas Terbuka, Jakarta, Indonesia. Her interests include development and effective use of learning materials for DE, information management, and inter-university collaboration.

\section{References}

Baggaley, J. (2007). Distance education technologies: An Asian perspective. Distance Education, 28(2), 125-131.

Baggaley, J., Belawati, T., Malik, N., \& Ng Lee Hoon, M. (2007). The PANdora model of collaborative distance education research. Distance Education, 28(2), 245-252.

Belawati, T. (1998). Increasing student persistence in Indonesian postsecondary distance education. Distance Education: An International Journal, 19(1), 81-108.

Belawati, T. (2005). The impact of online tutorials on course completion rates and student achievement. Learning, Media and Technology, 30(1), 15-25.

Belawati, T., \& Zuhairi, A. (2007). The practice of a quality assurance system in open and distance learning: A case study at Universitas Terbuka Indonesia (The Indonesia Open University). The International Review of Research in Open and Distance Learning, 8(1).

Daniel, J.S. (1996). Mega-universities and knowledge media: Technology strategies for higher education. London: Kogan Page.

Dimyati, S., Suciati, Hidayah, Z., Dewiki, S., Sugiman, \& Bachri, S. (2007, May). Utilization of teleconference technology for enhancing graduate studies interactive discourse: Tele-seminar on empowering Indonesian human resources development in the era of globalization. Proposal to the Direktorat General of Higher Education, Ministry of National Education, Indonesia. Jakarta, Indonesia: Universitas Terbuka.

Hardhono, A.P., \& Belawati, T. (1999). Final report base-line surveys for the utilization of faxinternet integration technology for distance learning support: A study conducted with funding assistance from the PAN Asia Networking. Jakarta, Indonesia: Universitas Terbuka. Retrieved March 9, 2008, from http://www.crdi.ca/en/ev-10426-201-1-DO_TOPIC.html

Jalal, F. (2006, April). Teacher's quality improvement in Indonesia: New paradigms and milestones. Report presented to the President of the World Bank. Jakarta, Indonesia: Ministry of National Education.

Jung, I. (2005). Quality assurance survey of mega universities. In C. McIntosh (Ed.), Perspectives on distance education: Lifelong learning and distance higher education (pp. 79-96). Vancouver, BC: Commonwealth of Learning \& UNESCO.

Jung, I. (2007). Changing faces of open and distance learning in Asia. The International Review of Research in Open and Distance Learning, 8(1).

Sardjiyo \& Pannen, P. (2006). Designing Web-based courses in distance education: Are we ready? Jurnal Pendidikan Terbuka Dan Jarak Jauh, 7(1), 34-42. 
Copyright of Distance Education is the property of Routledge and its content may not be copied or emailed to multiple sites or posted to a listserv without the copyright holder's express written permission. However, users may print, download, or email articles for individual use. 